\section{International Scientific Journal Theoretical \& Applied Science}

p-ISSN: 2308-4944 (print) e-ISSN: 2409-0085 (online)

Year: $2015 \quad$ Issue: $11 \quad$ Volume: 31

Published: $30.11 .2015 \quad$ http://T-Science.org
Dr. Sa'ad R Yousif

Faculty of Science / Dept. of Geology

Univ. of Kufa

Iraq

ali.alhameedawi@uokufa.edu.iq

Watheq F Shneen

Remote Sensing Centre

Univ. of Kufa

Iraq

SECTION 13. Geography. History. Oceanology. Meteorology.

\title{
LAND USE / COVER CHANGE DETECTION OF KUFA CITY, CENTRAL PART OF IRAQ USING REMOTE SENSING AND GIS TECHNIQUES
}

Abstract: The large population growth of the province of Najaf, the latest great pressure on the city of Kufa, and the lack of adequate housing areas within the administrative boundaries has resulted in an increase of slums to a crawl towards agricultural areas and bypassed outside the administrative design of the city. Remote Sensing and Geographic Information Systems (GIS) have the potential to provide accurate information regarding land use and land cover changes. This paper testifies the appropriate techniques utilized to detect land use and land cover changes and the effect of irregular expansion on the urban planning.

Key words: Geographic Information Systems, city of Kufa, land use, urban planning.

Language: English

Citation: Yousif SR, Shneen WF (2015) LAND USE / COVER CHANGE DETECTION OF KUFA CITY, CENTRAL PART OF IRAQ USING REMOTE SENSING AND GIS TECHNIQUES. ISJ Theoretical \& Applied Science 11 (31): 70-81.

Soi: http://s-o-i.org/1.1/TAS-11-31-13 Doi: crossef http://dx.doi.org/10.15863/TAS.2015.11.31.13

\section{Introduction}

Change detection has been defined as a "process of identifying differences in the state of an object or phenomenon by observing it in different times" (Singh 1989). This is considered an important process in monitoring land use/land cover changes, because it provides quantitative analysis of the spatial distribution of the population of interest and this makes land use/land cover study a topic of interest in remote sensing applications (Song et al. 2001, Gallego 2004). Land use/land cover changes are most important and typical applications of remote sensing data due to several factors such as urbanization and climate conditions. The process of urbanization has been characterized not only by population growth, but also by industrial expansion, increasing economic and social activities and intensified use of land resources (Pham et al. 2011). Furthermore, decision-makers are in constant need of current geospatial information on patterns and trends in land cover changes. Therefore, regular and up-todate information on urban change is required for urban planning, land use management and appropriate allocation of services and infrastructure within the urban areas (Baransley and Barr 1996).

Urban sprawl refers to excessive unusual growth near the periphery of the city boundary or in the places where there is the absence of planning and availability of basic amenities, these locations represented in Iraq by random housing or slummism. Cities need to grow in a planned and phased manner, and ensure a balance between proportion of growth and available resources. However rapid unplanned growth exerts pressure on the natural resources.

Satellite remote-sensing techniques have been widely used in detecting and monitoring land cover change at various scales with useful results [. Reis 2008, Diallo, et al 2009, and Muzein 2006]. This is due to their potential of providing accurate and timely geospatial information describing changes in urban land cover [Xiao, et al 2006]. The integration of remote sensing (RS) and Geographic Information Systems (GIS) has also been widely applied and recognized as an effective tools in detecting urban land-use/land-cover changes . Satellite remote sensing has the ability to collect multitemporal data and turns it into valuable information for monitoring urban land processes. GIS on the other hand provides a more flexible environment for entering, analysing and displaying digital data from various sources necessary for urban feature identification. These make remote sensing and GIS more useful tools for urban growth detection projects (Weng, 2001).

\section{The Objective}




\begin{tabular}{|c|c|c|c|c|c|c|}
\hline Impact Factor: & $\begin{array}{l}\text { ISRA (India) } \\
\text { ISI (Dubai, UAF } \\
\text { GIF (Australia) } \\
\text { JIF }\end{array}$ & $\begin{array}{l}=1.344 \\
=0.829 \\
=0.564 \\
=1.500\end{array}$ & $\begin{array}{l}\text { SIS (USA) } \\
\text { PИНЦ (Russia) } \\
\text { ESJI (KZ) } \\
\text { SJIF (Morocco) }\end{array}$ & $\begin{array}{l}=0.912 \\
=0.179 \\
=1.042 \\
=2.031\end{array}$ & $\begin{array}{l}\text { ICV (Poland) } \\
\text { PIF (India) }\end{array}$ & $\begin{array}{l}=6.630 \\
=1.940\end{array}$ \\
\hline
\end{tabular}

This study aims to use remotely sensed data and GIS together to monitor and characterize the urban sprawl in Al-Kufa City in terms of urban areas, availability of vegetation, soil and water bodies. The used approach is the comparative analysis using classification operation enables us to detect trend of land use/cover changes in different times.

\section{Study Area}

Al-Kufa City is subject to geographical location, as it is located on the Euphrates River, and 12 kilometers from An-Najaf City, 156 kilometers from Baghdad, 60 kilometers south of Karbala, and a few miles to the north-east of Al-Hira City. Its plain land, are high-elevated, and it rises 22 meters above sea level. The eastern bank is higher than the western one by almost six meters, which makes it safe from floods. Whenever we walked to the west, the surface rises gradually to reach 60.5 meters, and then descends steeper strongly toward the south-west to shallow salt lake that defined Bahr An-Najaf (Figure $1)$.

Ibn-Najim Marsh is located in the northeastern portion of the study area. The area of the water body influences by the seasonal changes in the Euphrates and the rate of rainfall.

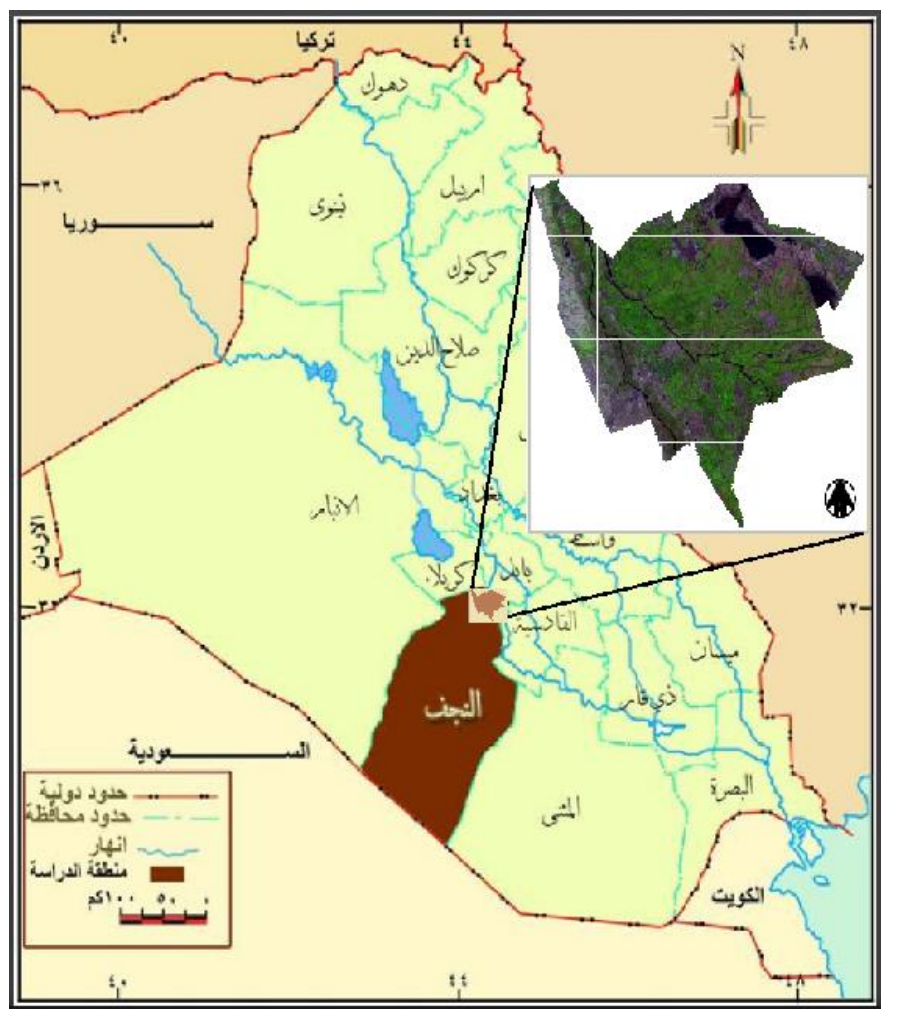

Figure 1 - Location of the study area.

\section{Materials and Methods}

\subsection{Data Preparation}

The following Landsat Images were used in the study in different sensors and dates; (A)(MSS in Oct 3,1976), (B)(TM in Aug 28,1990), (C)(ETM + in March 27, 2001), (D)(ETM + in March 28, 2006), (E) $\left(\right.$ ETM $^{+}$in July 27, 2013), (F)(ETM ${ }^{+}$in Apr 7, 2013), (G)(ETM ${ }^{+}$in March 23, 2014), and (H)(ETM + in Febr 06, 2015), (Figure 2). These images were processed using Erdas Imagine 2013 and ArcGIS 10.2. Besides the topographic maps of the study area with the scales of 1:100000 and 1:50000 are available.

\subsection{Land Use / Cover Change Detection and Analysis}

The two types of classification (i.e. unsupervised and supervised) has achieved on Landsat images to monitor vegetation cover and urbanization change detection of Al-Kufa City depending on the identification of all visible landmarks in the images. Image classification is perhaps the most important part of digital image analysis. With supervised classification, the information classes of interest like land cover type image. These are called "training sites". The image processing 


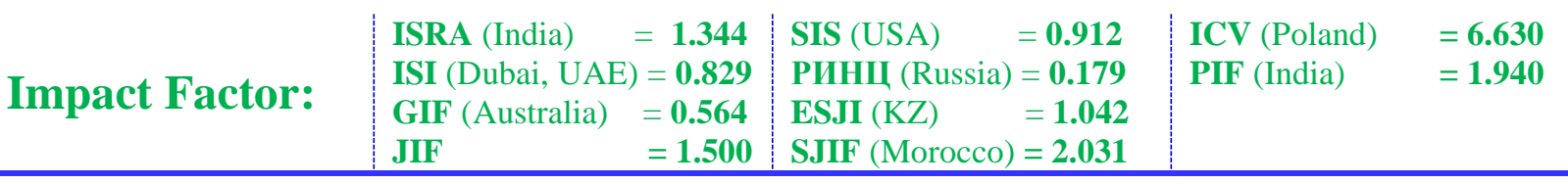
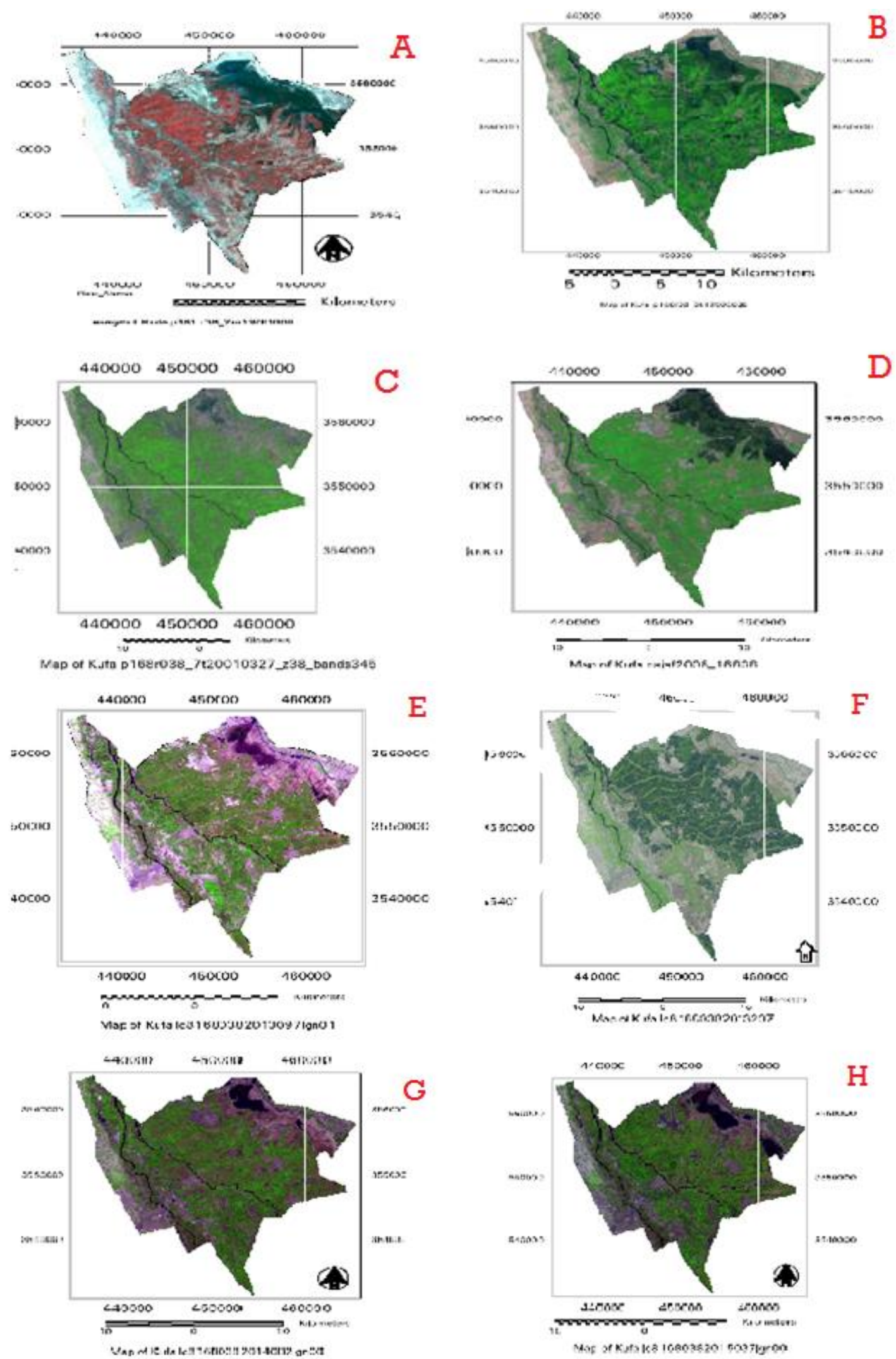

Figure 2 - The multi-temporal Landsat images used in the study.

Software system is then used to develop a statistical characterization of the reflectance for each information class. This stage is often called
"Signature analysis ".The error matrix and Kappa Khat methods were used to assess the mapping accuracy. Five land use / cover types are identified in 


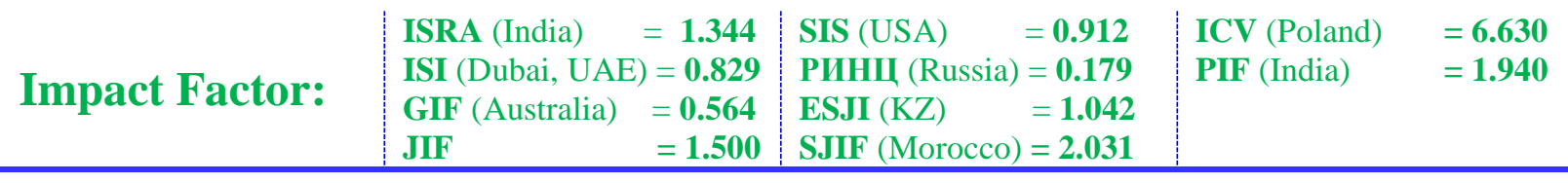

the study area viz., (1) vegetation and agricultural land (2) barren land (3) built-up land (4) water body (Figure 3).

Classified image pairs of the different decade's data were compared using cross-tabulation in order to determine qualitative and quantitative aspects of the changes for the periods from 1976 to 2015.

\section{Results and Discussion}

The results obtained through the analysis of multi-temporal satellite imageries were illustrated and data are registered in Table 1 which illustrates magnitude of change in different land categories. Tables (2-8) depict the accuracy assessment of the land use/cover analysis. A brief account of these results is discussed in the following paragraphs.

In 1976, the farmland was sparse as well as an excessive incoming waters to The Euphrates due to good monsoon rains during that period, and lack of population proliferation, which was stationed only in the centers of the cities without expansion, followed by 1999 , which was marked by a period of heavy rain, it was clear that the water bodies were extended at the expense of the agricultural areas. As for 2001, it turned into those bodies to barren tracts of land in addition to note a slight population growth. In 2006, it had reduced the cultivated areas owing to the circumstances of the country, as well as the expanding urban at the expense of agricultural land, this breadth encompassed the peripherals of the city and its environs, as well as the widening the areas that have been reclaimed for agriculture in the period before 2003, which is located to the east of Al-Kufa City where exploited random expansion of population.
We are, however, in the year 2013 and the subsequent expansion we have noted large population and all the random and systematic has been to the detriment of the agricultural area, especially the Al-Kufa City was surrounded by orchards, for its three parts, which had led to reduced agricultural land and the emergence of large areas of slum area such as Al-Barakiyah, south of Kufa, in addition to the areas of Abbasiya, Al-Hurriyah, and Al-Zarga that are extended to Al-Kufa by Missan Quarter.

Two images have been taking in the year of 2013 on April and July that it represents a peculiar attribute due to the large and distinguished change in spatial phenomena, including the expansion of population aggregates into towns and large towns such as Abbasiya, Al-Hira, and Al-Barakiyah due to the close location close to the centers of the cities as a result to the living conditions and the previous and current lack of support for housing, these phenomena came in the slums at the expense of agricultural land.

The agricultural land, which turned into residential areas, are in particular from the orchards, old Bay on the palm trees, and fruits, while the seasonal and cultivated areas that produce seasonal crops such as rice and corn (wheat) has not affected largely in this transformation. .

There is a difference in the expansion of agricultural area because of a lack of support and possibilities for irrigation and the adoption of farmers on the old methods in addition to the weakness of the reclamation of affected land, as evidenced by the appearance of the water in the rainy season, causing a phenomenon of salinity that was not processed and reclamated. This impact we can see clear in visual imagery in 1990 and 2001. 


\begin{tabular}{l|lrl|l|ll} 
& ISRA (India) & $=\mathbf{1 . 3 4 4}$ & SIS (USA) & $=\mathbf{0 . 9 1 2}$ & ICV (Poland) & $=\mathbf{6 . 6 3 0}$ \\
Impact Factor: & ISI (Dubai, UAE) $=\mathbf{0 . 8 2 9}$ & PUHU (Russia) $=\mathbf{0 . 1 7 9}$ & PIF (India) & $=\mathbf{1 . 9 4 0}$ \\
& GIF (Australia) & $\mathbf{0 . 5 6 4}$ & ESJI (KZ) & $=\mathbf{1 . 0 4 2}$ & & \\
& JIF & $=\mathbf{1 . 5 0 0}$ & SJIF (Morocco) $=\mathbf{2 . 0 3 1}$ & &
\end{tabular}
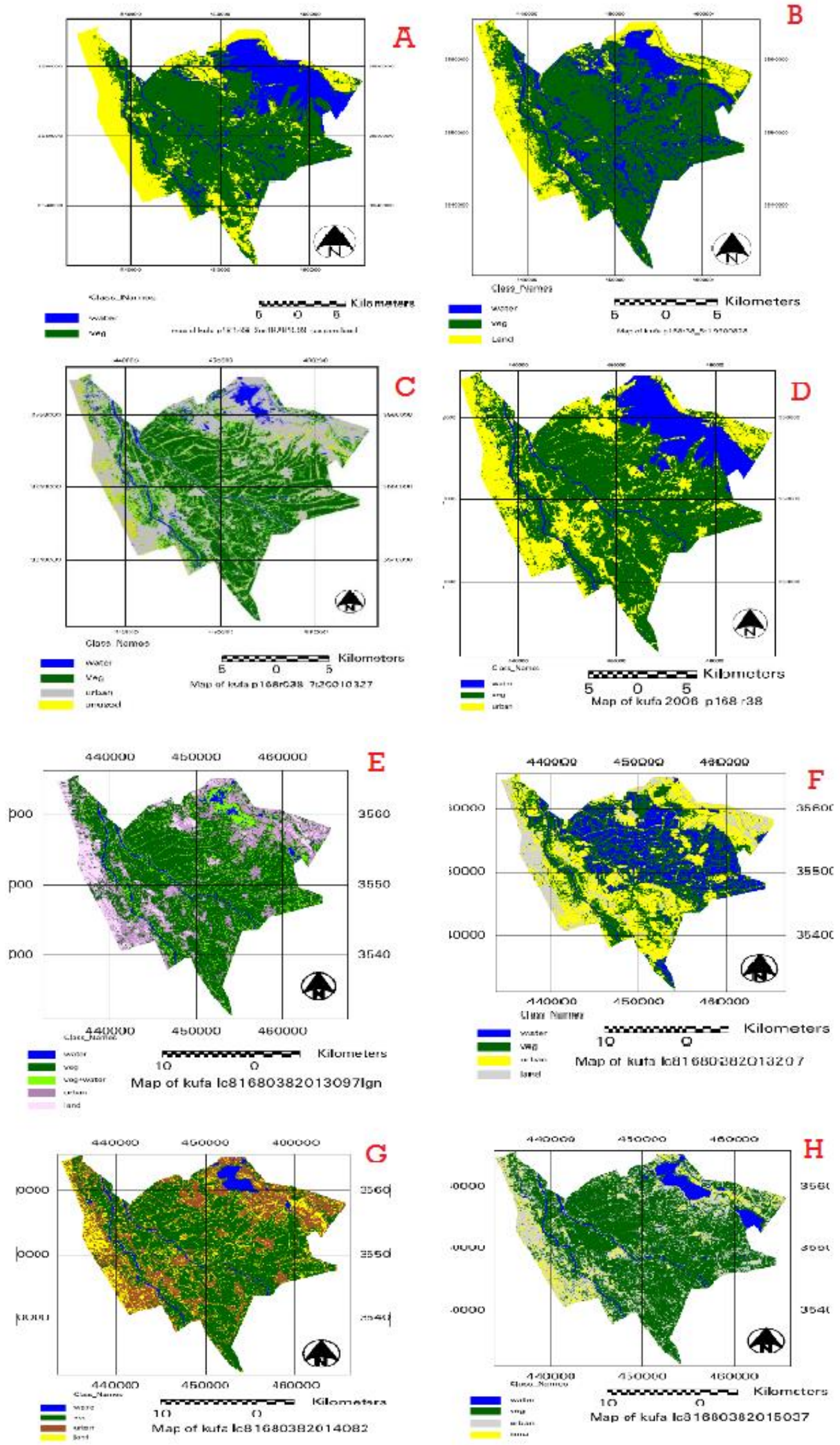

Figure 3 - Land use/cover change in different land use categories.

ISPC Technological advances, 


\begin{tabular}{l|lrl|l|ll} 
& ISRA (India) & $=\mathbf{1 . 3 4 4}$ & SIS (USA) & $=\mathbf{0 . 9 1 2}$ & ICV (Poland) & $=\mathbf{6 . 6 3 0}$ \\
Impact Factor: & ISI (Dubai, UAE) $=\mathbf{0 . 8 2 9}$ & PUHU (Russia) $=\mathbf{0 . 1 7 9}$ & PIF (India) & $=\mathbf{1 . 9 4 0}$ \\
& GIF (Australia) & $\mathbf{0 . 5 6 4}$ & ESJI (KZ) & $=\mathbf{1 . 0 4 2}$ & & \\
& JIF & $=1.500$ & SJIF (Morocco) & $=\mathbf{2 . 0 3 1}$ & &
\end{tabular}

Table 1

The calculations of the areas of the land use/cover categories (A) MSS in Oct 3,1976,(B) TM in Aug 28,1990, (C) ETM + in March 27, 2001, (D) ETM ${ }^{+}$in March 28, 2006,(E) ETM ${ }^{+}$in July 27, 2013, (F) ETM ${ }^{+}$in Apr 7, 2013, (G) ETM ${ }^{+}$in March 23, 2014 , and (H) ETM ${ }^{+}$in Feb 06, 2015 p181r38_2m19761003_usuperclassif.img

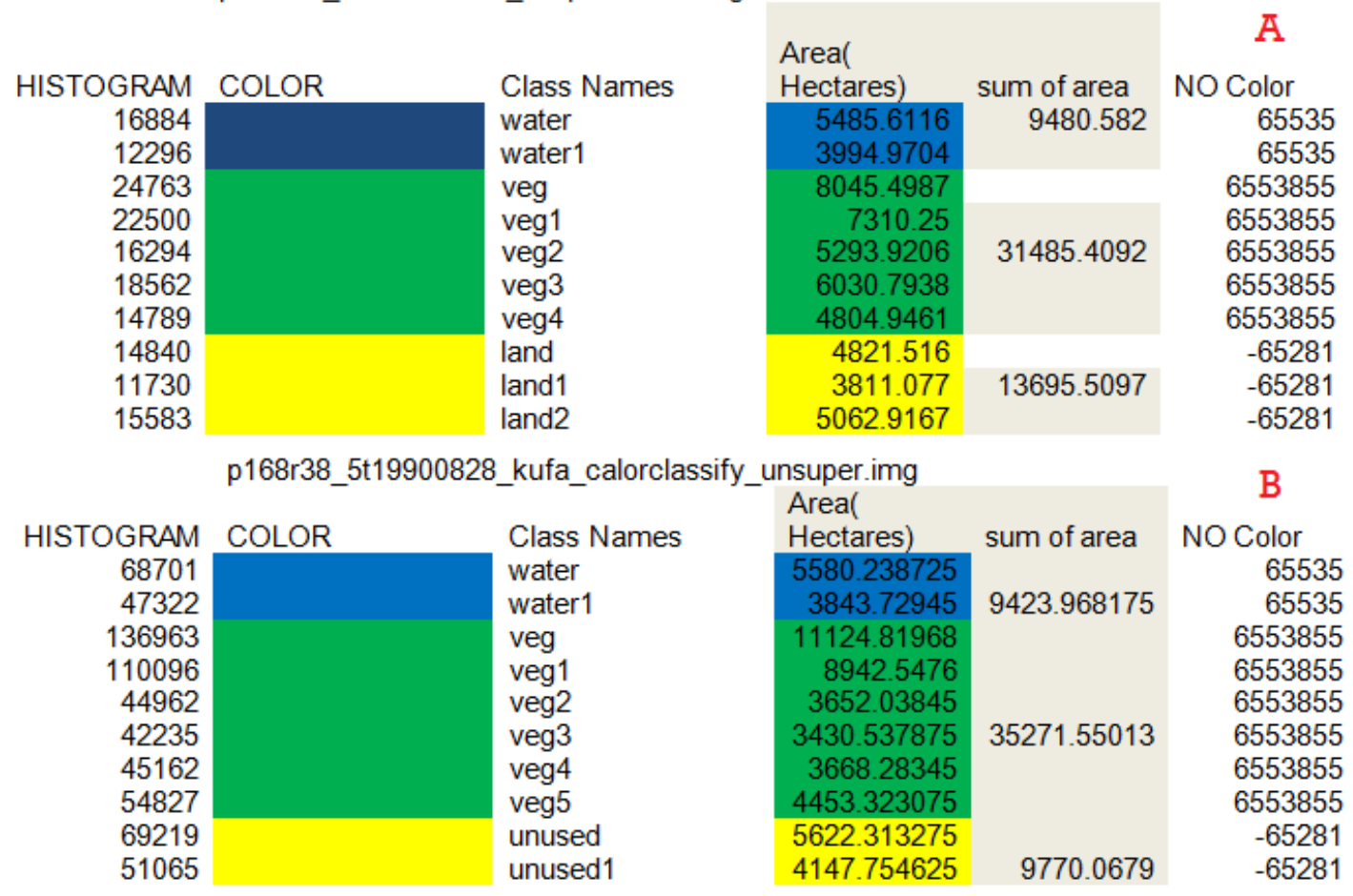

\begin{tabular}{|c|c|c|c|c|c|}
\hline \multicolumn{3}{|c|}{ unsuper_classif_kufa_p168r038_7t20010327.img } & Area( & & C \\
\hline HISTOGRAM & COLOR & Class Names & Hectares) & sum of area & NO Color \\
\hline 47165 & & water & 957.7466395 & 2805.883921 & 65535 \\
\hline 91013 & & water1 & 1848.137282 & & 65535 \\
\hline 304716 & & veg & 6187.654511 & & 6553855 \\
\hline 264415 & & veg1 & 5369.290315 & & 6553855 \\
\hline 206230 & & veg2 & 4187.768249 & & 6553855 \\
\hline 193486 & & old veg & 3928.984762 & 33887.72202 & 6553855 \\
\hline 195443 & & old veg1 & 3968.724191 & & 6553855 \\
\hline 178134 & & old veg2 & 3617.242444 & & 6553855 \\
\hline 194528 & & veg3 & 3950.143926 & & 6553855 \\
\hline 131876 & & new veg & 2677.913619 & & 6553855 \\
\hline 100547 & & urban3 & 2041.737546 & & 1061109505 \\
\hline 153286 & & urban2 & 3112.671502 & 13360.04273 & 1061109505 \\
\hline 195691 & & urban1 & 3973.760153 & & 1061109505 \\
\hline 208402 & & urban & 4231.873533 & & 1061109505 \\
\hline 92744 & & unused & 1883.287487 & & -65281 \\
\hline 120141 & & unused1 & 2439.619188 & 4322.906676 & -65281 \\
\hline
\end{tabular}




\begin{tabular}{|c|c|c|c|c|c|c|}
\hline Impact Factor: & $\begin{array}{l}\text { ISRA (India) } \\
\text { ISI (Dubai, UAE } \\
\text { GIF (Australia) } \\
\text { JIF }\end{array}$ & $\begin{array}{l}=1.344 \\
=0.829 \\
=0.564 \\
=1.500\end{array}$ & $\begin{array}{l}\text { SIS (USA) } \\
\text { PИНЦ (Russia) } \\
\text { ESJI (KZ) } \\
\text { SJIF (Morocco) }\end{array}$ & $\begin{array}{l}=0.912 \\
=0.179 \\
=1.042 \\
=2.031\end{array}$ & $\begin{array}{l}\text { ICV (Poland) } \\
\text { PIF (India) }\end{array}$ & $\begin{array}{l}=6.630 \\
=1.940\end{array}$ \\
\hline
\end{tabular}

Table 1 - continue

najaf2006_16838_kufa.img

\begin{tabular}{|c|c|c|c|c|c|}
\hline \multirow{11}{*}{$\begin{array}{r}\text { HISTOGRAM } \\
218636 \\
132958 \\
350729 \\
371156 \\
267658 \\
220392 \\
203378 \\
238527 \\
276850 \\
136352\end{array}$} & & & & & \\
\hline & COLOR & $\begin{array}{l}\text { Class Names } \\
\text { water }\end{array}$ & $\begin{array}{l}\text { Hectares) } \\
4919.31\end{array}$ & sum of area & \multirow{10}{*}{$\begin{array}{r}\text { NO Color } \\
65535 \\
65535 \\
6553855 \\
6553855 \\
6553855 \\
6553855 \\
6553855 \\
-65281 \\
-65281 \\
-65281\end{array}$} \\
\hline & & water1 & 2991.555 & \multirow[t]{3}{*}{7910.865} & \\
\hline & & veg & 7891.4025 & & \\
\hline & & veg1 & 8351.01 & & \\
\hline & & veg2 & 6022.305 & \multirow[t]{3}{*}{31799.5425} & \\
\hline & & veg3 & 4958.82 & & \\
\hline & & veg4 & 4576.005 & & \\
\hline & & urban & 5366.8575 & \multirow{3}{*}{14663.9025} & \\
\hline & & urban1 & 6229.125 & & \\
\hline & & & & & \\
\hline \multicolumn{5}{|c|}{ Ic81680382013097lgn01_kufa_classif_unsuper.img } & \multirow{9}{*}{$\begin{array}{r}E \\
\text { NO Color } \\
65535 \\
2147418367 \\
6553855 \\
6553855 \\
6553855 \\
6553855 \\
6553855\end{array}$} \\
\hline & & & $\begin{array}{l}\text { Area( } \\
\text { Hectares) }\end{array}$ & \multirow{4}{*}{$\begin{array}{r}\text { sum of area } \\
1352.025 \\
5355.9225\end{array}$} & \\
\hline 60090 & GULUR & water & 1352.025 & & \\
\hline 238041 & & veg+water & 5355.9225 & & \\
\hline 398528 & & & 8966.88 & & \\
\hline 425910 & & veg1 & 9582.975 & \multirow{4}{*}{31429.1025} & \\
\hline 273814 & & veg2 & 6160.815 & & \\
\hline 251515 & & veg3 & 5659.0875 & & \\
\hline 47082 & & veg4 & 1059.345 & & \\
\hline 271451 & & urban & 6107.6475 & \multirow{3}{*}{$\begin{array}{r}12646.9575 \\
3593.07\end{array}$} & \multirow{3}{*}{$\begin{array}{r}1350323713 \\
-811477249 \\
-35586049\end{array}$} \\
\hline 290636 & & urban1 & 6539.31 & & \\
\hline 159692 & & land & 3593.07 & & \\
\hline
\end{tabular}

\begin{tabular}{|c|c|c|c|c|c|}
\hline \multicolumn{5}{|c|}{ Ic81680382013207_kufa_classif_unsuper.img } & \multirow[b]{2}{*}{$\begin{array}{r}\text { NO Color } \\
65535 \\
6553855 \\
6553855 \\
6553855 \\
6553855 \\
6553855 \\
-65281 \\
-65281 \\
-65281 \\
-741092353\end{array}$} \\
\hline $\begin{array}{r}\text { HISTOGRAM } \\
472211 \\
330602 \\
173114 \\
23678 \\
147904 \\
207067 \\
202862 \\
247998 \\
346327 \\
264873\end{array}$ & COLOR & $\begin{array}{l}\text { Class Names } \\
\text { water } \\
\text { veg } \\
\text { veg1 } \\
\text { veg2 } \\
\text { veg3 } \\
\text { veg4 } \\
\text { urban2 } \\
\text { urban1 } \\
\text { urban } \\
\text { land }\end{array}$ & $\begin{array}{l}\text { Areal } \\
\text { Hectares) } \\
10624.7475 \\
7438.545 \\
3895.065 \\
532.755 \\
3327.84 \\
4659.0075 \\
4564.395 \\
5579.955 \\
7792.3575 \\
5959.6425\end{array}$ & $\begin{array}{l}\text { sum of area } \\
10624.7475 \\
19853.2125 \\
17936.7075 \\
5959.6425\end{array}$ & \\
\hline \multicolumn{5}{|c|}{ calssif_unsuperlc81680382014082.img } & G \\
\hline $\begin{array}{r}\text { HISTOGRAM } \\
84520 \\
296598 \\
397727 \\
365362 \\
235245 \\
157575 \\
247177\end{array}$ & COLOR & $\begin{array}{l}\text { Class Names } \\
\text { watre } \\
\text { veg1 } \\
\text { veg2 } \\
\text { veg3 } \\
\text { veg } \\
\text { land } \\
\text { land1 }\end{array}$ & $\begin{array}{r}\text { Areal } \\
\text { Hectares) } \\
1901.7 \\
6673.455 \\
8948.8575 \\
8220.645 \\
5293.0125 \\
3545.4375 \\
5561.4825\end{array}$ & $\begin{array}{r}\text { sum of area } \\
1901.7\end{array}$ & $\begin{array}{r}\text { NO Color } \\
65535 \\
6553855 \\
6553855 \\
6553855 \\
6553855 \\
-65281 \\
-65281\end{array}$ \\
\hline 230025 & & urban & 5175.5625 & & 1605292801 \\
\hline 114507 & & urban2 & 2576.4075 & 14229.72 & 1605292801 \\
\hline 287900 & & urban1 & 6477.75 & & 1605292801 \\
\hline
\end{tabular}

ISPC Technological advances, 


\begin{tabular}{l|ll|ll|ll} 
& ISRA (India) & $=\mathbf{1 . 3 4 4}$ & SIS (USA) & $=\mathbf{0 . 9 1 2}$ & ICV (Poland) & $=\mathbf{6 . 6 3 0}$ \\
Impact Factor: & ISI (Dubai, UAE) $=\mathbf{0 . 8 2 9}$ & PUHU (Russia) $=\mathbf{0 . 1 7 9}$ & PIF (India) & $=\mathbf{1 . 9 4 0}$ \\
& GIF (Australia) & $\mathbf{0 . 5 6 4}$ & ESJI (KZ) & $=\mathbf{1 . 0 4 2}$ & & \\
& JIF & $=1.500$ & SJIF (Morocco) & $=\mathbf{2 . 0 3 1}$ & &
\end{tabular}

Table 1 - continue

\begin{tabular}{|c|c|c|c|c|c|}
\hline \multirow[b]{2}{*}{ HISTOGRAM } & \multicolumn{4}{|c|}{ classif_unsuper2_Ic81680382015037.img } & \multirow{2}{*}{$\mathrm{H}$} \\
\hline & COLOR & Class Names & $\begin{array}{l}\text { Area( } \\
\text { Hectares) }\end{array}$ & sum of area & \\
\hline 139924 & & water & 3148.29 & 3148.29 & 65535 \\
\hline 258880 & & veg & 5824.8 & & 655385 \\
\hline 425853 & & veg1 & 9581.6925 & & 655385 \\
\hline 486164 & & veg2 & 10938.69 & 34202.7675 & 6553855 \\
\hline 349226 & & veg3 & 7857.585 & & 655385 \\
\hline 140847 & & land & 3169.0575 & 3169.0575 & $-652 \varepsilon$ \\
\hline 298246 & & urban & 6710.535 & & -74109235 \\
\hline 56740 & & urban2 & 1276.65 & & -7410923 \\
\hline 26227 & & urban3 & 590.1075 & 13854.195 & -74109235 \\
\hline 234529 & & urban4 & 5276.9025 & & -741092353 \\
\hline
\end{tabular}

Classification accuracy assessment report for MSS image in Oct 3,1976.

Table 2

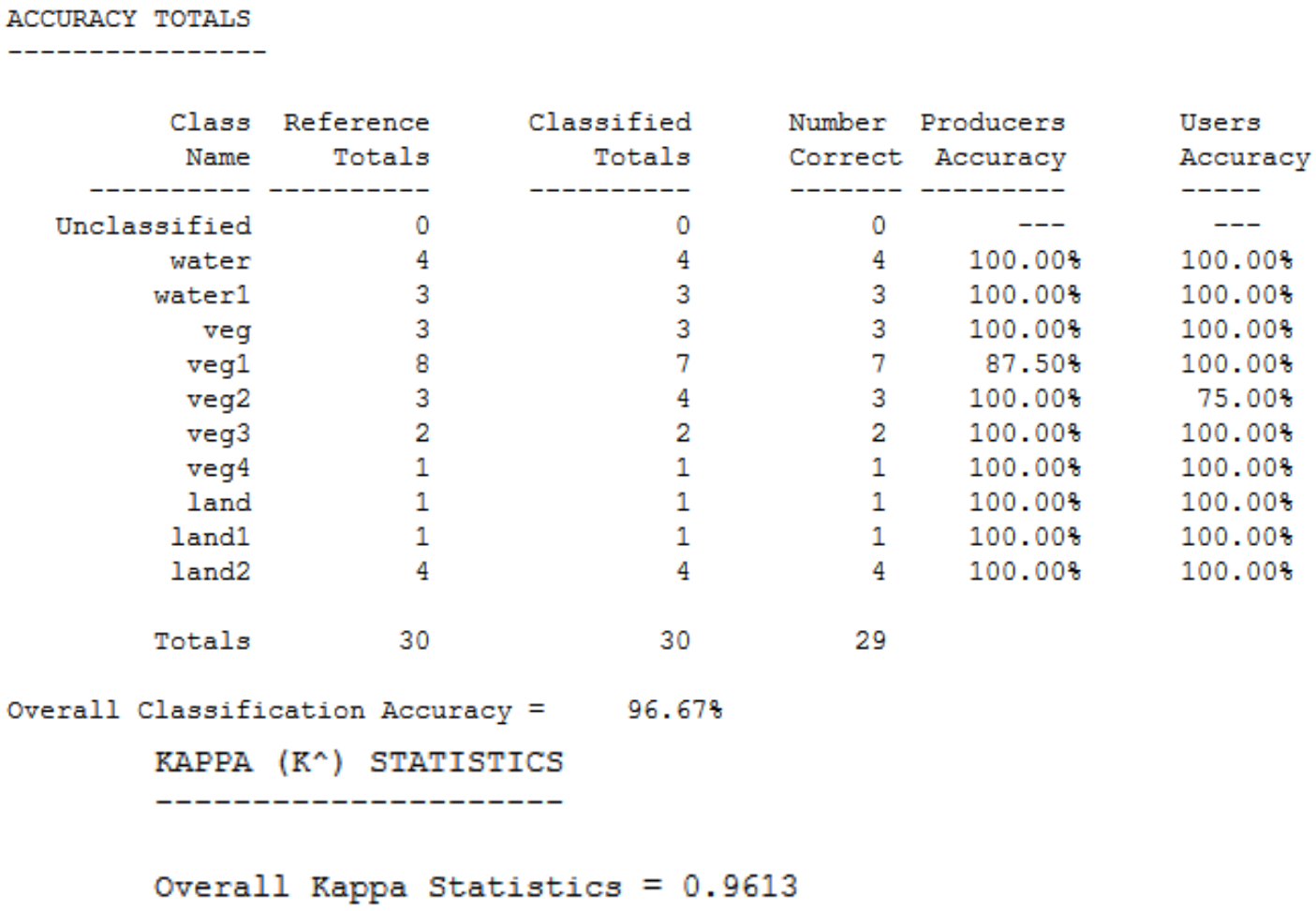

ISPC Technological advances, 


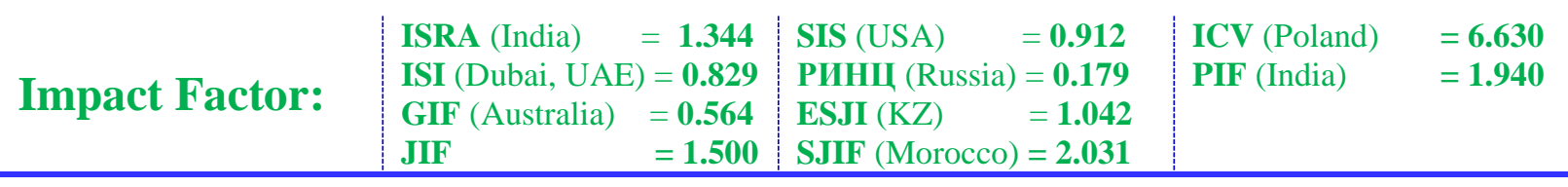

Classification accuracy assessment report for TM image in Aug. 28, 1990.

Table 3

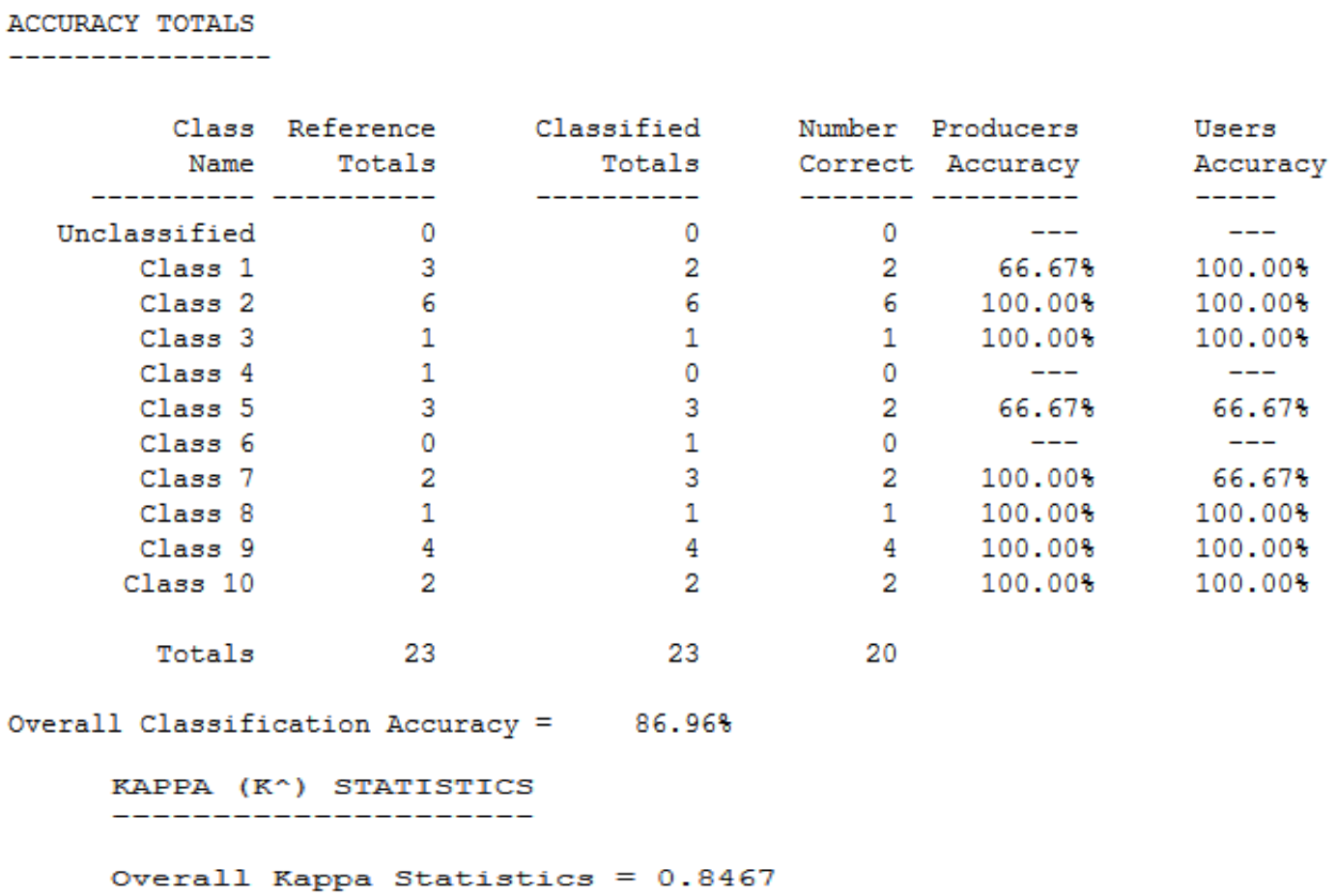

Table 4

Classification accuracy assessment report for $\mathrm{ETM}^{+}$image in March 27,2001.

$\begin{array}{rr}\text { ACCURACY TOTALS } & \\ \text { Class } & \text { Reference } \\ \text { Name } & \text { Totals } \\ \text { water } & 0 \\ \text { veg } & 1 \\ \text { veg1 } & 1 \\ \text { veg2 } & 3 \\ \text { old veg } & 0 \\ \text { old veg1 } & 2 \\ \text { old veg2 } & 0 \\ \text { new veg } & 1 \\ \text { water1 } & 3 \\ \text { urban3 } & 1 \\ \text { veg3 } & 1 \\ \text { urban2 } & 0 \\ \text { unused1 } & 2 \\ \text { urban1 } & 0 \\ \text { urban } & 3 \\ \text { unused } & 1 \\ \text { Totals } & 1 \\ & 20\end{array}$
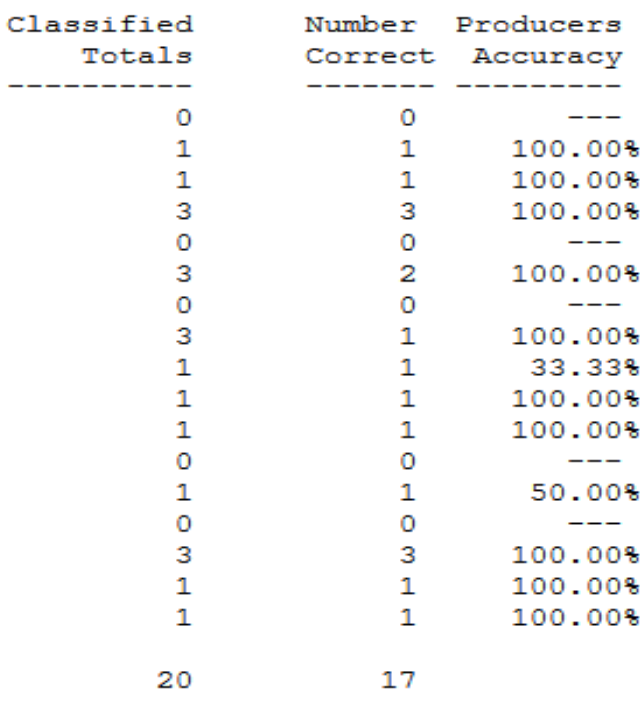

Users

Accurac

-----

100.008

100.008

100.008

66.678

$---$

33.338

100.008

100.008

100.008

100.008

$---$

100.008

100.008

100.008

Overall Classification Accuracy =

85.008

KAPPA (K^) STATISTICS

Overall Kappa Statistics $=0.8343$

ISPC Technological advances, 


\begin{tabular}{l|lrl|l|ll} 
& ISRA (India) & $=\mathbf{1 . 3 4 4}$ & SIS (USA) & $=\mathbf{0 . 9 1 2}$ & ICV (Poland) & $=\mathbf{6 . 6 3 0}$ \\
Impact Factor: & ISI (Dubai, UAE) $=\mathbf{0 . 8 2 9}$ & PUHU (Russia) $=\mathbf{0 . 1 7 9}$ & PIF (India) & $=\mathbf{1 . 9 4 0}$ \\
& GIF (Australia) & $\mathbf{0 . 5 6 4}$ & ESJI (KZ) & $=\mathbf{1 . 0 4 2}$ & & \\
& JIF & $=1.500$ & SJIF (Morocco) & $=\mathbf{2 . 0 3 1}$ & &
\end{tabular}

Classification accuracy assessment report for $\mathrm{ETM}^{+}$image in March 28, 2006.

Table 5

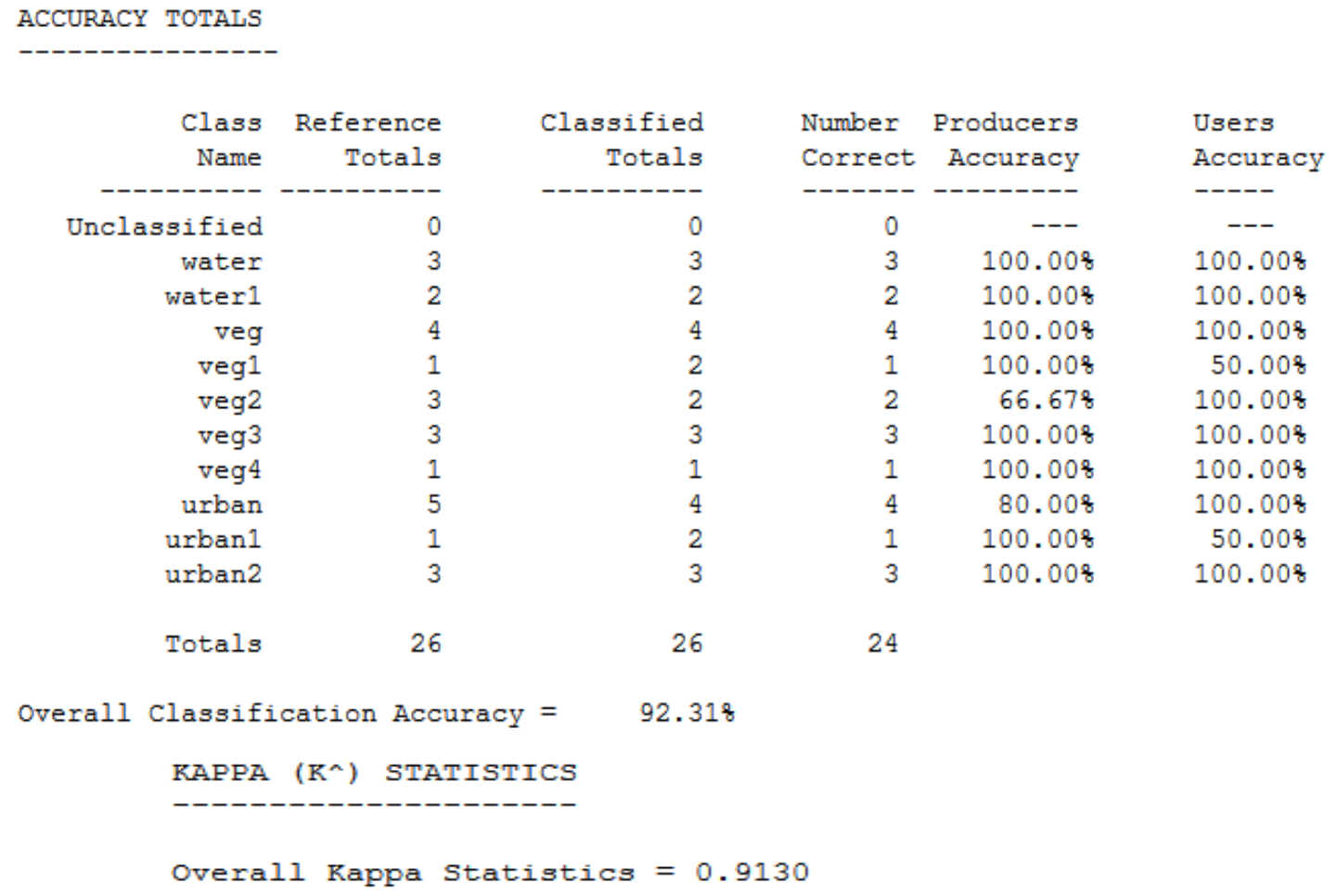

Classification accuracy assessment report for $\mathrm{ETM}^{+}$image in Apr. 07, 2013.

Table 6

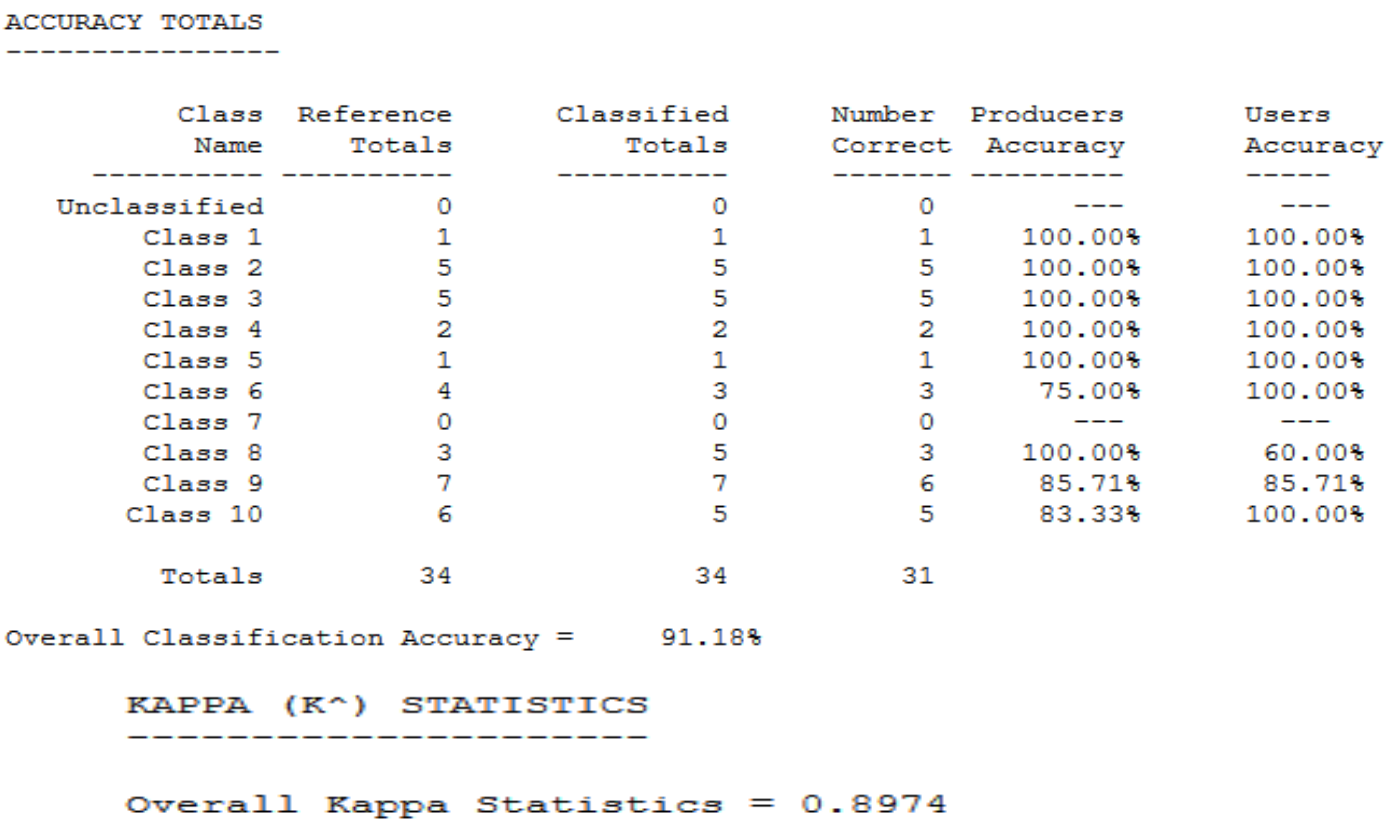

ISPC Technological advances, 


\begin{tabular}{l|lrl|l|ll} 
& ISRA (India) & $=\mathbf{1 . 3 4 4}$ & SIS (USA) & $=\mathbf{0 . 9 1 2}$ & ICV (Poland) & $=\mathbf{6 . 6 3 0}$ \\
Impact Factor: & ISI (Dubai, UAE) $=\mathbf{0 . 8 2 9}$ & PUHU (Russia) $=\mathbf{0 . 1 7 9}$ & PIF (India) & $=\mathbf{1 . 9 4 0}$ \\
& GIF (Australia) & $\mathbf{0 . 5 6 4}$ & ESJI (KZ) & $=\mathbf{1 . 0 4 2}$ & & \\
& JIF & $=1.500$ & SJIF (Morocco) & $=\mathbf{2 . 0 3 1}$ & &
\end{tabular}

Classification accuracy assessment report for ETM $^{+}$image in March 23, 2014.

Table 7

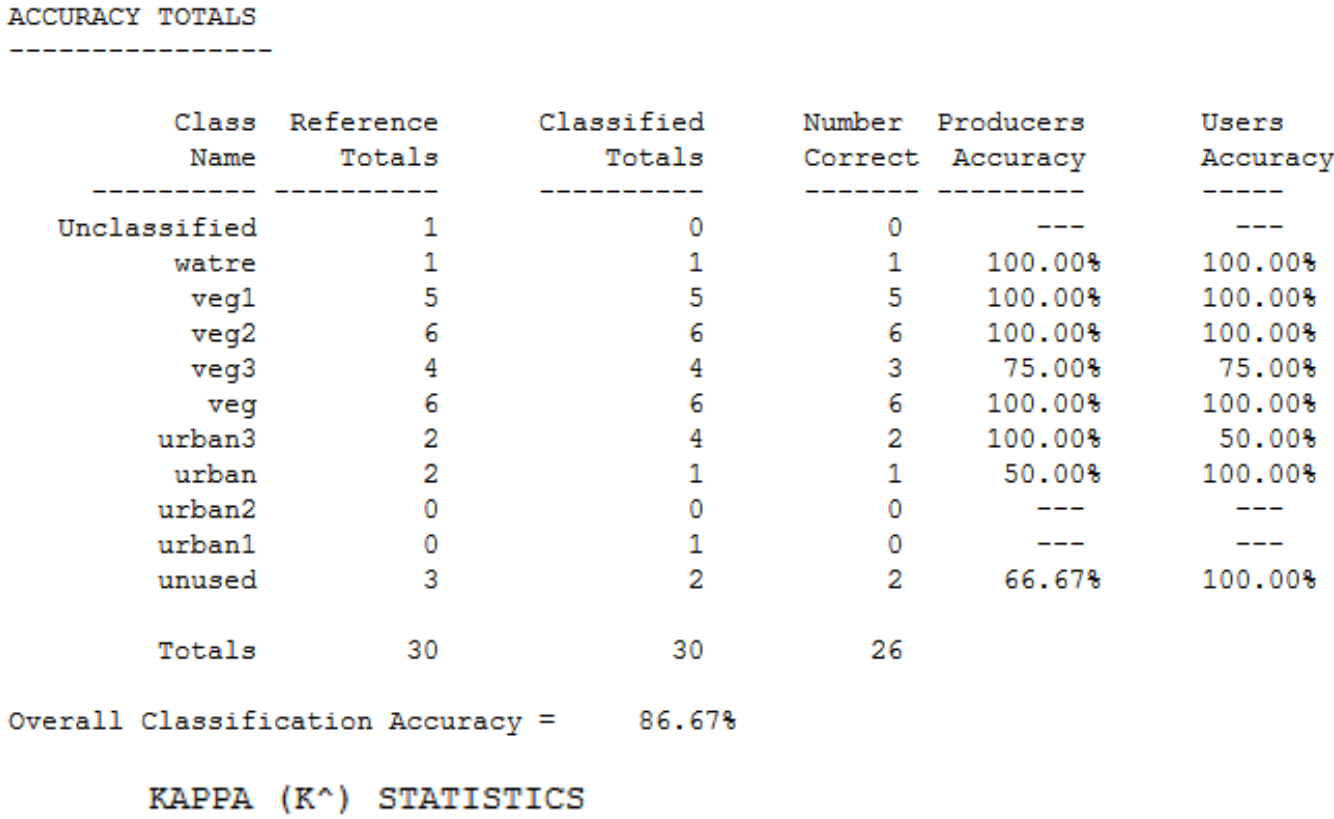

Overall Kappa Statistics $=0.8442$

Classification accuracy assessment report for $\mathrm{ETM}^{+}$image in Feb. 06, 2015.

Table 8 ACCURACY TOTALS

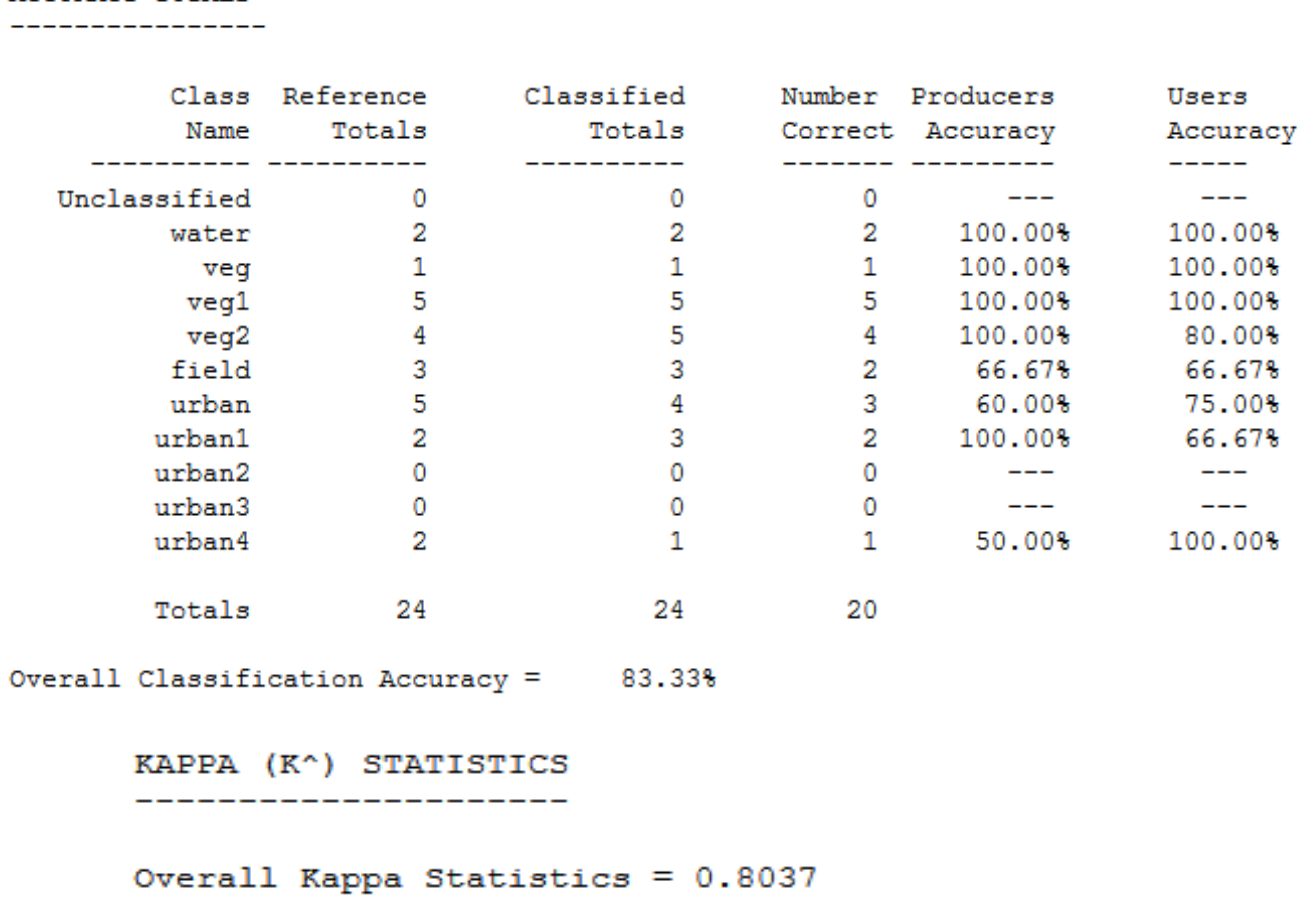

ISPC Technological advances, 


\begin{tabular}{l|lrl|l|ll} 
& ISRA (India) & $=\mathbf{1 . 3 4 4}$ & SIS (USA) & $=\mathbf{0 . 9 1 2}$ & ICV (Poland) & $=\mathbf{6 . 6 3 0}$ \\
Impact Factor: & ISI (Dubai, UAE) $=\mathbf{0 . 8 2 9}$ & PUHIL (Russia) $=\mathbf{0 . 1 7 9}$ & PIF (India) & $=\mathbf{1 . 9 4 0}$ \\
& GIF (Australia) & $\mathbf{0 . 5 6 4}$ & ESJI (KZ) & $=\mathbf{1 . 0 4 2}$ & & \\
\hline JIF & $=\mathbf{1 . 5 0 0}$ & SJIF (Morocco) $=\mathbf{2 . 0 3 1}$ & & \\
\hline
\end{tabular}

\section{References:}

1. Baransley MJ, Barr SJ (1996) Inferring urban land use from satellite sensor images using kernel-based spatial reclassification. Photogrammetric Engineering \& Remote Sensing., vol. 62, no.8, pp: 949-958.

2. Diallo Y, Hu G, Wen X (2009) Applications of remote sensing in land use / land cover change detection in Puer and Simao Counties, Yunnan Province, Journal of American Science, vol.5, no.4, pp:157-166.

3. Gallego FJ (2004) "Remote sensing and land cover area estimation", International Journal of Remote Sensing, vol. 25, no. 15, pp. 30193047.

4. Muzein BS (2006) Remote Sensing \& GIS for Land Cover/ Land Use Change Detection and Analysis in the Semi-Natural Ecosystems and Agriculture Landscapes of the Central Ethiopian Rift Valley, (Unpub.) Ph.D. thesis, Technische Universität Dresden, Germany,166 p.

5. Pham HM, Yamaguchi Y, Bui TQ (2011) A case study on the relation between city planning and urban growth using remote sensing and spatial metrics, Landscape and Urban Planning, vol. 100, no.3, pp: 223-230.
6. Reis S (2008) Analyzing Land Use/Land Cover Changes Using Remote Sensing and GIS in Rize, North-East Turkey, Sensors, vol.8, pp:6188-6202.

7. Singh A (1989) "Digital change detection techniques using remotelysensed data", International Journal of Remote Sensing, vol. 10, no. 6, pp. 989-1003.

8. Song C, Woodcock CE, Seto KC, Lenney MP, Macomber SA (2001) "Classification and Change Detection Using Landsat TM Data: When and How to Correct Atmospheric Effects?", Remote Sensing of Environment, vol. 75, no. 2, pp. 230-244.

9. Weng Q (2001) Remote Sensing - GIS Evaluation of Urban Expansion and its Impact on Surface Temperature in the Zhujiang Delta, China, International Journal of Remote Sensing, Vol. 22 No. 10, pp: 1999-2014.

10. Xiao J, Shen Y, Ge J, Tateishi R, Tang C, Liang Y, Huang Z (2006) Evaluating urban expansion and land use change in Shijiazhuang, China, by using GIS and remote sensing. Landscape and Urban Planning, vol.75, pp:69-80. 